\title{
Vitamin D Levels in Female Depressive Psychotic Patients
}

\author{
DALIA R. IBRAHIM, Ph.D.* and EMAN M. MAHMOUD, Ph.D.** \\ The Department of Biological Applications, Nuclear Research Center, Atomic Energy Authority* and \\ The Department of Clinical Pathology, Abou Al-Azayem Hospital**, Cairo, Egypt
}

\begin{abstract}
Background: Vitamin D is a neurosteroid hormone of a central role in CNS development and function and its insufficiency is associated with cognitive impairments. Major Depression Disorder (MDD) is a mental disorder that is affected by diet and nutritional factors.

Aim of Study: The present study was carried out to assess the levels of vitamin D in depressive psychotic female patients and to compare its levels with the control group.

Subjects and Methods: Eighty female subjects participated in this study, 40 inpatients in Abou Al-Azayem Psychiatric Hospital, Cairo, Egypt, suffering from major depressive disorder, and 40 healthy control volunteers. Vitamin D concentration, Thyroid stimulating hormone (TSH), Aspartate Aminotransferase (AST), alanine aminotransferase (ALT), urea, creatinine and fasting glucose were evaluated in serum.

Results: The results showed that vitamin D levels were significantly lower in the depressive psychotic group compared to the control group. Meanwhile, there were significant increases in urea concentrations in the depressive group compared to the control one. The two groups (depressive psychotic and control) on the other hand, showed insignificant changes in TSH, AST, ALT, creatinine and fasting glucose levels.

Conclusion: Depressive psychotic patients suffered from vitamin D deficiency and insufficiency therefore, vitamin D supplementation maybe effective in the treatment of depression and lowering the depressive symptoms.
\end{abstract}

Key Words: Vitamin D-Psychosis - Major depressive disorder.

\section{Introduction}

MAJOR Depression Disorder (MDD) is a worldwide mental disorder that affects the functioning and quality of life and causes health and economic burden [1]. Lifestyle factors such as physical activity

Correspondence to: Dr. Dalia R. Ibrahim, The Department of Biological Applications, Nuclear Research Center, Atomic Energy Authority, Cairo, Egypt and diet quality might be risk factors to mental disorders [2,3]. Vitamin D is one of the nutritional components that might have an important role in mental health [4]. Vitamin D is influenced by many cofactors such as seasonal [5], environmental and genetic factors [6]. Many risk factors cause vitamin D deficiency such as ageing, obesity, female sex, winter season, dark skin pigmentation, anxiety, eating disorders [7-9], impaired liver function, renal and cardiovascular diseases [10,11]. Vitamn D is found in two forms: Vitamin D2 (ergocalciferol) and Vitamin D3 (cholecalciferol). Vitamin D2 is available in dietary products such as plants and fish, while vitamin D3 is synthesized in the skin when exposed to Ultraviolet B (UVB) rays from sunlight [12]. The marker of Vitamin D status is serum 25-Hydroxyvitamin D [25-(OH)D], which is the main circulating metabolite of Vitamin D [13]. The US Endocrine Society defines Vitamin D deficiency as $25-(\mathrm{OH}) \mathrm{D}$ less than $20 \mathrm{ng} / \mathrm{ml}$, Vitamin D insufficiency as $25-(\mathrm{OH}) \mathrm{D}$ between 20 and $30 \mathrm{ng} / \mathrm{ml}$, and Vitamin D sufficiency as 25$(\mathrm{OH}) \mathrm{D}$ greater than $30 \mathrm{ng} / \mathrm{ml}$ [10]

The presence of Vitamin D [25-(OH)D] in cerebrospinal fluid suggests that Vitamin D may play a role in brain development [14]. Previous studies reported that alterations in serum Vitamin $\mathrm{D}$ level are associated with changes in brain volume [15-18]. Moreover, the presence of Vitamin D receptor and vitamin D metabolizing enzymes $[\mathbf{1 9 , 2 0}]$ in the human nervous system (CNS) indicates that Vitamin D may have a functional role in the nervous system [21,22]. Vitamin D is involved in signaling cascades and neurobiological pathways [23]. The active metabolite $1,25(\mathrm{OH}) 2 \mathrm{D} 3$ is thought to regulate the maturation and differentiation of dopaminergic neurons [24] and affect the levels of brain serotonin [23-25]. It is suggested that Vitamin $\mathrm{D}$ may have a role in the emotional and cognitive 
functions $[\mathbf{2 1 , 2 6 , 2 7 ]}$. This may indicate that there is an association between serum Vitamin D level, total intracranial volume and the depressive mood. The present study aims at assessing the levels of Vitamin D in female depressive psychotic patients and to compare its levels with the control group.

\section{Subjects and Methods}

\section{1-Patients:}

This study was performed on 80 female subjects divided into two equal groups. The depressive psychotic group, consisted of 40 in patients in Abou Al-Azayem Psychiatric Hospital, Cairo, Egypt (from February to June, 2019), suffering from Major Depressive Disorder (MDD), age ranged from 35 to 48 years, and the control group, consisted of 40 healthy females, age ranged from 37 to 45 years. Clinical psychiatrists confirmed the diagnosis of depression in accordance with the International Classification of Diseases Criteria. All patients were receiving their regular antidepressant medications. Clinical and laboratory examinations were performed to exclude severe somatic diseases, diabetes, liver or renal diseases and overt or subclinical thyroid diseases.

\section{2- Collection of blood samples and biochemical analysis:}

After fasting for 6-8 hours, $5 \mathrm{ml}$ venous blood was drawn from each participant for laboratory investigations. The blood was centrifuged at 2000xg for $10 \mathrm{~min}$. Serum was separated and stored at $-80^{\circ} \mathrm{C}$ until further analysis. Vitamin D level was measured using radioimmunoassay kit (DiaSorin, Stillwater, Minnesota, U.S.A). Quantitative determination of TSH was assayed utilizing RIA kit (MP Biomedicals, China). Fasting glucose was measured using enzymatic technique (Vitro Scientific). The liver enzymes, namely, AST and ALT were measured using kinetic technique (Diacan). Urea and creatinine analyses were carried out using Jaffe Kinetic methods. The apparatus used for biochemical analysis was TICO (USA) semiautomated spectrophotometer. Complete Blood Count (CBC) was carried out using MICROS 3 differential full automated hematology counter (France).

\section{3- Compliance and ethical standards:}

All procedures performed involving human participants were in accordance with the ethical standards of the institutional and national research committee and with the 1964 Helsinki declaration and its later amendments or comparable ethical standards. Informed consents were obtained from all participants after they had been given a complete description of the study.

\section{4- Statistical analysis:}

Data were analyzed with the statistical package for social sciences (SPSS, version 20 for windows, Chicago, USA). Results were expressed as percentages $(\%)$ or mean \pm standard deviation. Paired Student Test ( $t$-test) was carried out for the statistical analysis studies of the mean values of the experimental parameters. $p<0.001$ was considered statistically significant.

\section{Results}

In the present study, the age of the control group ranged from 37 to 45 years with mean \pm SD (39.80 \pm 3.12 ), while the age of the depressive psychotic group ranged from 35 to 48 years with mean \pm SD $(41.30 \pm 3.81)$. All the participants were females. Table (1) illustrates the levels of Vitamin D in the controls and the depressive psychotic patients. Among the 40 psychotic patients, 26 patients $(65 \%)$ were classified as deficient Vitamin D $(<20 \mathrm{ng} / \mathrm{ml})$ and 14 patients (35\%) were classified as insufficient Vitamin D (20-30ng/ml). In the control group, 30 subjects (75\%) were classified as sufficient Vitamin D (30-100ng/ml) and 10 subjects $(25 \%)$ were classified as insufficient Vitamin D.

Table (1): Level of Vitamin D in the controls and depressive psychotic groups.

\begin{tabular}{lcc}
\hline Total Vitamin D & $\begin{array}{c}\text { Control } \\
(\%)\end{array}$ & $\begin{array}{c}\text { Depressive } \\
\text { Psychotic } \\
\text { patients } \\
(\%)\end{array}$ \\
\hline Deficient $<20 \mathrm{ng} / \mathrm{ml}$ & $10(25 \%)$ & $14(35 \%)$ \\
Insufficient $20-30 \mathrm{ng} / \mathrm{ml}$ & $30(75 \%)$ & \\
Sufficient 30-100ng/ml & 40 & 40 \\
\hline Total & $465)$ \\
\hline
\end{tabular}

The analysis of the biochemical parameters in (Table 2) revealed that there were significant decreases in Vitamin D levels in the depressive psychotic group compared to the control group. Meanwhile, the urea concentrations significantly increased in the depressive group compared to the control group, but they are within the normal range. The two groups (depressive psychotic and control) on the other hand, showed insignificant changes in TSH, AST, ALT, creatinine and fasting glucose levels and all their results were within the normal range. 
Table (2): Serum Vitamin D, TSH, AST, ALT, urea, creatinine and fasting glucose in the controls and depressive psychotic groups.

\begin{tabular}{llll}
\hline & \multicolumn{1}{c}{ Control } \\
& & $\begin{array}{c}\text { Depressive } \\
\text { Psychotic patients } \\
(\text { mean } \pm \text { SD) }\end{array}$ & $\begin{array}{c}p \text { - } \\
\text { value }\end{array}$ \\
\hline Vitamin D (ng/ml) & $34.82 \pm 9.06$ & $19.87^{* *} \pm 3.14$ & 0.001 \\
TSH (mIU/L) & $1.89 \pm 1.06$ & $2.32 \pm 1.34$ & 0.264 \\
AST (IU/L) & $16.05 \pm 2.96$ & $16.90 \pm 5.32$ & 0.536 \\
ALT (IU/L) & $17.20 \pm 3.02$ & $16.70 \pm 5.73$ & 0.732 \\
Urea (mg/dl) & $14.30 \pm 2.70$ & $24.85^{* *} \pm 8.30$ & 0.001 \\
Creatinine (mg/dl) & $0.82 \pm 0.17$ & $0.76 \pm 0.15$ & 0.204 \\
F. glucose (mg/dl) & $96.60 \pm 19.04$ & $90.25 \pm 22.71$ & 0.344 \\
\hline
\end{tabular}

The data are presented as mean $\pm \mathrm{SD}$.

Significant at $p<0.001 * *$.

\section{Discussion}

In the present study, the authors investigated the relation between Vitamin D deficiency and the psychiatric diagnosis of depression. All the depressive patients had Vitamin D insufficiency or deficiency, and the serum concentrations of Vitamin D were significantly lower among depressive patients compared to healthy controls, which agreed with previous studies [28,29]. Previous publications also reported that low serum Vitamin D level was associated with more severe depressive symptoms $[30,31]$. It has been proved that Vitamin D has neuroprotective effects and that higher serum Vitamin $D$ levels are associated with reduced risk of depression [32,33].

The effects of Vitamin D on brain development and function have been previously studied [23] These studies reported that depletion of Vitamin $\mathrm{D}$ is related to the decrease in the brain volume and the increase in the lateral cerebral ventricles [15]. It was found that in older adults, Vitamin D deficiency is associated with the increase in the white matter volume [17] and the decrease in the hippocampal volume [16]. Meanwhile, in healthy young women, low Vitamin D serum concentration has been linked to the increase in the Total Intracranial Volume (TIV), total cortical gray and cerebral white matter volumes [18]. These results suggest that Vitamin D has neuroanatomical effects on depressive patients. On the other hand, Zhu et al., [30] found that patients with severe depressive symptoms had reduced total intracranial volume compared to patients with non severe depressive symptoms, and that there is a negative effect of Vitamin D serum level on the severity of depressive symptoms in major depressive disorder patients which is mediated by total intracranial volume.

Von Kanel et al., [31], investigated the relationship between Vitamin D deficiency and psychiatric diagnosis of depression in hospitalized patients. They found that Vitamin D deficiency at 25-(OH) D levels $<50 \mathrm{nmol} / 1(<20 \mathrm{ng} / \mathrm{ml})$ was significantly associated with the increase in the depressive symptoms in the hospitalized depressive patients. Vitamin D deficiency is significantly associated with cognitive/affective symptoms of depression, but less with somatic/affective ones. Patients with Vitamin D deficiency had more depressive symptoms than those with Vitamin D insufficiency, while patients with insufficient Vitamin D had higher cognitive/affective symptom scores than those with sufficient Vitamin D.

Vitamin D supplementation with at least 800 I.U. daily is favorable in the management of depression [34] and may increase the effect of antidepressants in major depressive disorder patients [35] There is current evidence that adjunctive use of Vitamin D with antidepressants can reduce depressive symptoms more effectively [36]. Song et al., [37] and Wang et al., [38] found that Vitamin D supplementation is effective in the treatment of depression and in lowering the depressive symptoms.

Neurobiological and neuroendocrine mechanisms have been suggested for the link between Vitamin D deficiency and depressive symptoms. Vitamin $\mathrm{D}$ has a role in brain areas processing depressive mood [39], in dopaminergic and serotoninergic function [40,41], and in constraining systematic inflammation being associated with depression [42].

In this study, serum urea concentrations are significantly increased in depressive patients compared to healthy controls, but they are within the normal range. Some antidepressants are kidney toxic, such as lithium, and damage the kidney of the patients elevating the urea level in blood [43].

The findings of the present study showed no significant differences in the serum TSH between individuals with depression and healthy controls. Their measures were within the normal range. Overt or subclinical thyroid disease was one of the exclusion criteria in the current study. Thyroid hormones (FT3 and FT4) are distributed widely in the central nervous system. They play a role in the development of cerebellum and cerebral cortex [44] and regulation of neural growth [45]. Studies have reported that depression is associated with changes in the Hypothalamic-Pitutary-Thyroid (HPT) axis [46] and there is a positive correlation between depression and overt hypothyroidism [47] It was also reported that there is an association of 
Vitamin D deficiency with hypothyroidism and that Vitamin D is inversely related to TSH [48].

The results of liver enzymes (AST and ALT) were also within the normal range and there were insignificant differences between individuals suffering depression and healthy controls. Patients with liver diseases were excluded from this study as Vitamin D deficiency has been reported in previous studies to be associated with chronic liver diseases [49] and chronic hepatitis $\mathrm{C}$ virus infection [50].

In the present study, it has been shown that depressive psychotic patients suffered from Vitamin D deficiency or insufficiency. Therefore, assessment and supplementation of Vitamin D should become a routine in the treatment of depressed patients, as a promising new approach in treating depression. On the other hand, maintaining optimum Vitamin D levels is highly favorable in preventing depression.

\section{References}

1- SHERCHAND O., SAPKOTA N., CHAUDHARI R.K., KHAN S.A., BARANWAL J.K., POKHREL T., et al.: Association between Vitamin D deficiency and depression in Nepalese population. Psychiatry Res., 267: 266-71, doi: 10.1016/j. psychres.2018.06.018, 2018.

2- JACKA F.N., KREMER P.J., LESLIE E.R., BERK M., PATTON G.C., TOUMBOUROU J.W. and WILLIAMS J.W.: Associations between diet quality and depressed mood in adolescents: Results from the Australian healthy Neighbourhoods study. Aust. N. Z. J. Psychiatry, 44 (5): 435-42, 2010

3- JACKA F.N., PASCO J.A., WILLIAMS L.J., LESLIE E.R., DODD S., NICHOLSON G.C., KOTOWICZ M.A. and BERK M.: Lower levels of physical activity in childhood associated with adult depression. Aust. J. Sci. Med. Sport., 14 (3): 222-6, 2011.

4- FÖCKER M., ANTEL J., RING S., HAHN D., KANAL O., OZTURK D., HEBEBRAND J. and LIBUDA L.: Vitamin D and mental health in children and adolescents. Eur. Child Adolesc. Psychiatry, 26 (9): 1043-66, 2017.

5- SCHRAMM S., LAHNER H., JOCKEL K.H., ERBEL R., FUHRER D. and MOEBUS S.: Heinz Nixdorf recall study G: Impact of season and different Vitamin D thresholds on prevalence of vitamin D deficiency in epidemiological cohorts-a note of caution. Endocrine, 56 (3): 65866, 2017.

6- WANG T.J., ZHANG F., RICHARDS J.B., KESTENBAUM B., VAN MEURS J.B., BERRY D., KIEL D.P., STREETEN E.A., OHLSSON C., KOLLER D.L., et al.: Common genetic determinants of vitamin D insufficiency: A genome-wide association study. Lancet, 376 (9736): 180-8, 2010.

7- HOSSEIN-NEZHAD A. and HOLICK M.F.: Vitamin D for health: A global perspective. Mayo. Clin. Proc., 88: 720-55. doi: 10.1016/j.mayocp.2013.05.011 PMID: 23790560, 2013.
8- MADDOCK J., BERRY D.J., GEOFFROY M.C., POWER C. and HYPPÖNEN E.: Vitamin D and common mental disorders in mid-life: Cross-sectional and prospective findings. Clin. Nutr., 32: 758-64. doi: 10.1016/j.clnu. 2013.01.006 PMID: 23395104, 2013.

9- MODAN-MOSES D., LEVY-SHRAGA Y., PINHASHAMIEL O., KOCHAVI B., ENOCH-LEVY A., VERED I., et al.: High prevalence of Vitamin D deficiency and insufficiency in adolescent inpatients diagnosed with eating disorders. Int. J. Eat. Disord., 48 (6): 607-14. doi: 10.1002/eat.22347, 2015.

10- HOLICK M.F., BINKLEY N.C., BISCHOFF-FERRARI H.A., GORDON C.M., HANLEY D.A., HEANEY R.P., et al.: Evaluation, treatment, and prevention of Vitamin D deficiency: An Endocrine Society clinical practice guideline. J. Clin. Endocrinol. Metab., 96: 1911-30. doi: 10.1210/jc.2011-0385 PMID: 21646368, 2011.

11-PRAMYOTHIN P. and HOLICK M.F.: Vitamin D supplementation: Guidelines and evidence for subclinical deficiency. Curr. Opin. Gastroenterol., 28: 139-50. doi: 10.1097 /MOG. 0b013e32835004dc PMID: 22274617, 2012.

12- KULIE T., GROFF A., REDMER J., HOUNSHELL J. and SCHRAGER S.: Vitamin D: An evidence-based review. J. Am. Board Fam. Med., 22: 698-706. doi: 10.3122/jabfm. 2009.06.090037, 2009.

13- HOLICK M.F.: Vitamin D deficiency. N. Engl. J. Med., 357: 266-81. doi: 10.1056/NEJMra070553, 2007.

14- BALABANOVA S., RICHTER H.P., ANTONIADIS G., HOMOKI J., KREMMER N., HANLE J., et al.: 25Hydroxyvitamin D, 24, 25-dihydroxyvitamin D and 1, 25-dihydroxyvitamin D in human cerebrospinal fluid. Klin. Wochenschr., 62: 1086-90. doi: 10.1007/ BF01711378, 1984.

15- ANNWEILER C., ANNWEILER T., MONTEROODASSO M., BARTHA R. and BEAUCHET O.: Vitamin $\mathrm{D}$ and brain volumetric changes: Systematic review and meta-analysis. Maturitas, 78: 30-9. doi: 10.1016/j. maturitas.2014.02.013, 2014.

16- KARAKIS I., PASE M.P., BEISER A., BOOTH S.L., JACQUES P.F., ROGERS G., et al.: Association of serum vitamin $D$ with the risk of incident dementia and subclinical indices of brain aging: The Framingham Heart Study. J. Alzheimers Dis., 51: 451-61. doi: 10.3233/JAD-150991, 2016.

17- ANNWEILER C., BARTHA R., KARRAS S.N., GAUTIER J., ROCHE F. and BEAUCHET O.: Vitamin D and white matter abnormalities in older adults: A quantitative volumetric analysis of brain MRI. Exp. Gerontol., 63: 41-7. doi: 10.1016/j. exger.2015.01.049, 2015.

18- PLOZER E., ALTBACKER A., DARNAI G., PERLAKI G., ORSI G., NAGY S.A., et al.: Intracranial volume inversely correlates with serum $25(\mathrm{OH}) \mathrm{D}$ level in healthy young women. Nutr. Neurosci., 18: 37-40. doi: 10.1179/ 1476830514Y.0000000109, 2015.

19- OBRADOVIC D., GRONEMEYER H., LUTZ B. and REIN T.: Cross-talk of Vitamin D and glucocorticoids in hippocampal cells. J. Neurochem., 96 (2): 500-9, 2006.

20- De ABREU D.A.F., EYLES D. and FÉRON F.: Vitamin D, a neuro-immunomodulator: Implications for neurodegenerative and autoimmune diseases. Psychoneuroendo- 
crinology, 34 (1): S265-77. doi:10.1016/j. psyneuen. 2009.05.023, 2009.

21- EYLES D.W., SMITH S., KINOBE R., HEWISON M. and MCGRATH J.J.: Distribution of the Vitamin D receptor and 1 alpha-hydroxylase in human brain. J. Chem. Neuroanat., 29: 21-30. doi: 10.1016/j.jchemneu.2004. 08.006, 2005.

22- SUTHERLAND M.K., SOMERVILLE M.J., YOONG L.K., BERGERON C., HAUSSLER M.R. and MCLACHLAN D.R.: Reduction of vitamin D hormone receptor mRNA levels in Alzheimer as compared to Huntington hippocampus: Correlation with calbindin-28k mRNA levels. Brain Res. Mol. Brain Res., 13: 239-50. doi: 10.1016/0169-328X(92)90032-7, 1992.

23- EYLES D.W., BURNE T.H. and MCGRATH J.J.: Vitamin $\mathrm{D}$, effects on brain development, adult brain function and the links between low levels of Vitamin D and neuropsychiatric disease. Front Neuroendocrinol., 34 (1): 47-64, 2013.

24- CUI X., PERTILE R., LIU P. and EYLES D.W.: Vitamin $D$ regulates tyrosine hydroxylase expression: $\mathrm{N}$-cadherin a possible mediator. Neuroscience, 304: 90-100, 2015.

25- GARCION E., WION-BARBOT N., MONTERO-MENEI C.N., BERGER F. and WION D.: New clues about Vitamin $\mathrm{D}$ functions in the nervous system. Trends Endocrinol. Metab., 13 (3): 100-5, 2002.

26- Di SOMMA C., SCARANO E., BARREA L., ZHUKOUSKAYA V.V., SAVASTANO S., MELE C., et al.: Vitamin D and neurological diseases: An endocrine view. Int. J. Mol. Sci., 18: 2482. doi: 10.3390/ijms18112482, 2017.

27- SCHLOGL M. and HOLICK M.F.: Vitamin D and neurocognitive function. Clin. Interv. Aging., 9: 559-68. doi: 10.2147/CIA.S51785, 2014.

28- HOOGENDIJK W.J., LIPS P., DIK M.G., DEEG D.J., BEEKMAN A.T. and PENNINX B.W.: Depression is associated with decreased 25-hydroxyvitamin D and increased parathyroid hormone levels in older adults. Arch. Gen. Psychiatry, 65: 508-12. doi: 10.1001/archpsyc. 65.5.508, 2008.

29- JOZEFOWICZ O., RABE-JABLONSKA J., WOZNIACKA A. and STRZELECKI D.: Analysis of Vitamin D status in major depression. J. Psychiatr. Pract., 20: 32937. doi: 10.1097/ 01.pra.0000454777.21810.15, 2014.

30- DAO-MIN ZHU, WENMING ZHAO, BIAO ZHANG, YU ZHANG, YING YANG, CUN ZHANG, YAJUN WANG, JIAJIA ZHU and YONGQIANG YU: The Relationship Between Serum Concentration of Vitamin D, Total Intracranial Volume, and Severity of Depressive Symptoms in Patients With Major Depressive Disorder. Front Psychiatry, 10: 322. doi: 10.3389/fpsyt.2019.00322, 2019.

31- ROLAND VON KÄNEL, NASSER FARDAD, NADINE STEURER, NICOLE HORAK, ESTHER HINDERMANN, FRANZ FISCHER and KATHARINA GESSLER: Vitamin D Deficiency and Depressive Symptomatology in Psychiatric Patients Hospitalized with a Current Depressive Episode: A Factor Analytic Study PLoS One, 10 (9): e0138550. doi: 10.1371/journal.pone. 0138550, 2015.
32- KALUEFF A.V., EREMIN K.O. and TUOHIMAA P.: Mechanisms of neuroprotective action of vitamin $\mathrm{D}(3)$. Biochemistry (Mosc), 69: 738-41. doi: 10.1023/B:BIRY. 0000040196.65686.2f, 2004.

33- JAASKELAINEN T., KNEKT P., SUVISAARI J., MANNISTO S., PARTONEN T., SAAKSJARVI K., et al.: Higher serum 25-hydroxyvitamin D concentrations are related to a reduced risk of depression. Br. J. Nutr., 113: 1418-26. doi: 10.1017/ S0007114515000689, 2015.

34- SPEDDING S.: Vitamin D and depression: A systematic review and meta-analysis comparing studies with and without biological flaws. Nutrients, 6: 1501-18. doi: 10.3390/nu6041501, 2014.

35- WILLIAMS J.A., SINK K.M., TOOZE J.A., ATKINSON H.H., CAULEY J.A., YAFFE K., et al.: Low 25hydroxyvitamin $\mathrm{D}$ concentrations predict incident depression in well-functioning older adults: The health, aging, and body composition study. J. Gerontol. A. Biol. Sci. Med. Sci., 70: 757-63. doi: 10.1093/gerona/glu184, 2015.

36- SARRIS J., MURPHY J., MISCHOULON D., PAPAKOSTAS G.I., FAVA M., BERK M., et al.: Adjunctive nutraceuticals for depression: A systematic review and metaanalyses. Am. J. Psychiatry, 173: 575-87. doi: 10.1176/ appi.ajp.2016.15091228, 2016.

37- SONG E.K., WU J.R., MOSER D.K., KANG S.M. and LENNIE T.A.: Vitamin D supplements reduce depressive symptoms and cardiac events in heart failure patients with moderate to severe depressive symptoms. Eur. J. Cardiovasc. Nurs., 17: 207-16. doi: 10.1177/ 147451511 $7727741,2018$.

38- WONG S.K., CHIN K.Y. and IMA-NIRWANA S.: Vitamin $\mathrm{D}$ and depression: The evidence from an indirect clue to treatment strategy. Curr. Drug Targets, 19: 888-97. doi: 10.2174/1389450118666170913161030, 2018.

39- HARMS L.R., BURNE T.H., EYLES D.W. and MCGRATH J.J.: Vitamin D and the brain. Best Pract. Res. Clin. Endocrinol. Metab., 35: 657-69, 2011.

40- PATRICK R.P. and AMES B.N.: Vitamin D hormone regulates serotonin synthesis. Part 1: Relevance for autism. FASEB J., 28: 2398-413. doi: 10.1096/fj.13-246546 PMID: 24558199, 2014.

41- CUI X.1., PELEKANOS M., LIU P.Y., BURNE T.H., MCGRATH J.J. and EYLES D.W.: The vitamin D receptor in dopamine neurons; its presence in human substantia nigra and its ontogenesis in rat midbrain. Neuroscience, 236: 77-87. doi: 10.1016/j.neuro science. 2013.01.035 PMID: 23352937, 2013.

42- BERK M., WILLIAMS L.J., JACKA F.N., O'NEIL A., PASCO J.A., MOYLAN S., et al.: So depression is an inflammatory disease, but where does the inflammation come from? BMC Med., 11: 200. doi: 10.1186/17417015-11-200 PMID: 24228900, 2013.

43- GUPTA S. and KHASTGIR U.: Drug information update. Lithium and chronic kidney disease: Debates and dilemmas. B. J. Psych. Bulletin., 41: 216-20, 2017.

44- CHATONNET F., PICOU F., FAUQUIER T. and FLAMANT F.: Thyroid hormone action in cerebellum and cerebral cortex development. J. Thyroid. Res., 2011: $145762,2011$. 
45- KAPOOR R., FANIBUNDA S.E., DESOUZA L.A., GUHA S.K. and VAIDYA V.A.: Perspectives on thyroid hormone action in adult neurogenesis. J. Neurochem., 133: 599-616, 2015.

46- BROUWER J.P., APPELHOF B.C., HOOGENDIJK W.J., HUYSER J., ENDERT E., ZUKETTO C., et al.: Thyroid and adrenal axis in major depression: A controlled study in outpatients. Eur. J. Endocrinol., 152 (2): 185-91, 2005.

47- CONSTANT E.L., ADAM S., SERON X., BRUYER R., SEGHERS A. and DAUMERIE C.: Hypothyroidism and major depression: A common executive dysfunction? J. Clin. Exp. Neuropsychol., 28 (5): 790-807, 2006.

48- ELRAWI H.A., GHANEM N.S., ELSAYED N.M., ALI H.M., RASHED L.A. and MANSOUR M.M.: Study of
Vitamin D Level and Vitamin D Receptor Polymorphism in Hypothyroid Egyptian Patients. J. Thyroid Res., 2019: 3583250, doi: 10.1155/2019/3583250, 2019.

49- ARTEH J., NARRA S. and NAIR S.: Prevalence of Vitamin D deficiency in chronic liver disease. Dig. Dis. Sci., 55: 2624-8. DOI: 10.1007/s10620-009-1069-9, 2010.

50- LANGE C.M., BOJUNGA J., RAMOS-LOPEZ E., VON WAGNER M., HASSLER A., VERMEHREN J., HERRMANN E., BADENHOOP K., ZEUZEM S. and SAR RAZIN C.: Vitamin D deficiency and a CYP27B1-1260 promoter polymorphism are associated with chronic hepatitis $\mathrm{C}$ and poor response to interferon-alfa based therapy. J. Hepatol., 54: 887-93. DOI: 10.1016/ j.jhep.2010. 08.036, 2011.

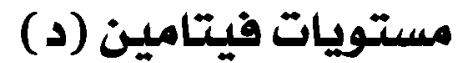 فى إناث مرضى الإكتئاب الذيتهانى (دئى}

فيتامين (د) هو هرمون عصبى له دود مركزى فى تطوير الجهاز العصبى المركزى وإنخفاض مستوى فيتامين (د) ويرتبط بضعف الإدراك.

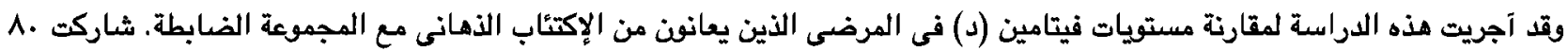

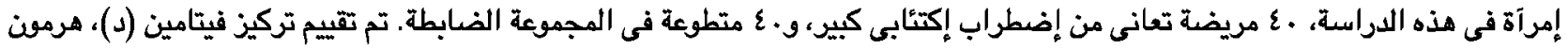

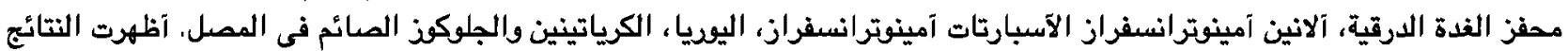

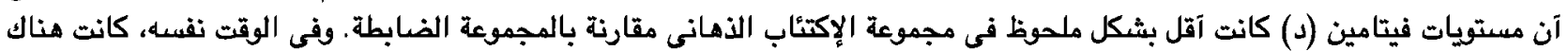

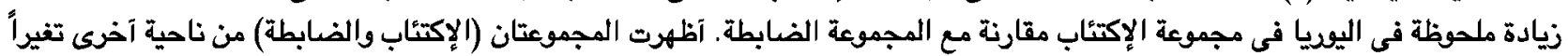

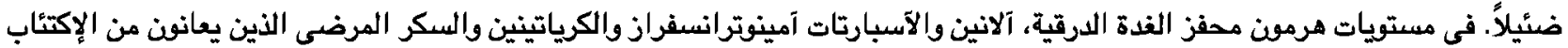

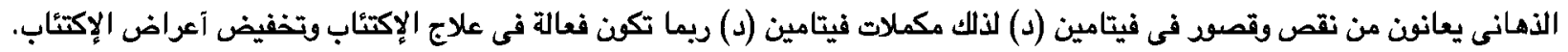

